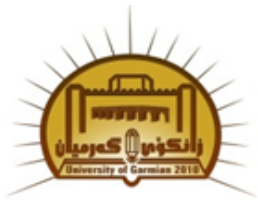

Available online at http://jgu.garmian.edu.krd

Journal of Uni versity of Garmian

https://doi.org/10.24271/garmian.1037

\title{
Overt and Institutional Racism in Maya Angelou's Selected Poems
}

\author{
Snoor Ismael Mahmood
}

English Department, College of Education, University of Garmian,

\section{Article Info}

Received: March, 2019

Revised:March,2019

Accepted:M arch,2019

\section{Keywords}

African American Literature, racial segregation, overt and institutional racism, Maya Angelou.

Corresponding Author snoor.ismael@garmian.edu.krd

\begin{abstract}
Maya Angelou is an Afro-American poet who has written poems that are simple in language and deep in meaning. This research is a socio-racial study of Maya Angelou's selected poems from her first collection; Just Give Me a Cool Drink of Water 'fore I Diiie (1971). It uses sociological criticism to analyze the poems; first, the paper covers the background and the social condition of the emergence of African American literature. It highlights the nature of their literary works in relation to their social life and racial segregation that they encountered. Secondly, it defines racism and its different types, overt and institutional racism as a part of the societal life in the United States of America. To clarify these two types of racism in the poems of Maya Angelou, the poems are analyzed in relation to the racial theories of overt and institutional racism. Finally, the study concludes that Maya Angelou's poems expose racial discrimination and prejudice with the aim of reforming the social life of African American people, and ends with a list of the works cited.
\end{abstract}

\section{Introduction}

Marguerite Annie Johnson ( April 4, 1928 - May $28,2014)$ is an African American writer who has experienced a rich life. She has worked as a dancer, actor, poet, singer, playwright, and civil right activist. She lived in different parts of America and with different people that helped her to get an insight about the lives of the African Americans during 1930s till 2000s. From her early childhood as she was living in Stamps, a racially segregated society in Arkansas in Deep South, she experienced racism and the inferiority of African American. She longed to be blonde to live a life without discrimination. In South, while she was a child, she witnessed harassment and insult when white girls were insulting and mocking adult black Americans and her grandmother, just because of the color of their skin. Not only on street but also in public place, she experienced racial discrimination (Cox 1120).

In the late 1950s she was in New York, in spite of being an actor and activist, she was busy with literary and civil activities. She arranged a fundraiser called "Cabaret for Freedom" to support 
Martin Luther King Jr., who was a leader and spokesperson of civil right movement. Later on, she was appointed as a Northern Coordinator of the Southern Christian Leadership Conference (SCLC), a position she held briefly from 1959 to 1960. After 1960 she moved to Middle East there she worked as an editor of a newspaper in 1961 and worked in School of Music and Drama in University of Ghana(Bloom 10-12). In her literary works, she has tried to address social issues based on her own ideology and social experience and cultural background of their lives throughout different periods. As they have lived through slavery, Jim craw era, racial segregation that continued till 1964 and several riots to get freedom.

After the liberation of the black people from slavery and being a citizen, racial discrimination and individual racial attitude continued to exist especially in the Southern States. These tensions between two different races led to the beginning of Negro problem and racial segregation in 1870s and 1880s. Therefore legislator in South issued Jim crow law that supported segregation by law. They thought that it is the best solution for Negro problem. The separation of the black and white people were legal since they were separate and equal, means that they were provided the same facilities but differently( Massy and Denton 83-84) According to Jim Crow law both the white and black people have separate accesses to social and public services. So the black cannot go to the same school of the white, or restaurant, hospital, bathroom, drink form the same water foundation, or sit in front of white in bus, they should not live in the same accommodation era. They did not have the same chance of employment this limited their economical advancement.

Maya tries to address racism inside the society with the aim of social reform as she says "I speak to the black experience, but I am always talking about the human condition-about what we can endure, dream, fail at and still survive" (qtd. in Cox 10). She wants to write for her race and also for the people regardless of their race, she writes for eliminating racism and bringing about social equality.

\section{Racism in Maya Angelou's Selected Poems}

To understand the meaning of race and racism in any country, one ought to have an insight to the socio-historical situation of that area. Hence racism can be defined from different perspectives. Simply speaking racism is a dislike and disapproval of a person or a group of people who are different from you. And this attitude leads to segregation, hegemony, and discrimination, as it is defined in Random House Dictionary of the English Language Racism is "a belief or doctrine that inherent differences among the various human racial groups determine cultural or individualachievement, usually involving the idea that one's own race is superior and has the right to dominate others "(qtd. in Bugeja 192).

Racism can emerge from cultural differences between different groups. A group of people regards its own culture to be superior and morally more appropriate, that secures the superiority of one group over the other. Hence a group is regarded inferior to the superior one. In the United States of America, as W.E.B. DuDois argues, racism has brought about a circumstance in which black people look at themselves "through the eyes of others" (qtd. in Martinot $\mathrm{xvi})$. This kind of consciousness originates from the fact of being outsider in a country because of your different color, culture and race.

It can also be based on the physical appearance of a group of people that are differentiated because of their skin color, hair, eye color and shape of their body in a way they are shunned by individuals of other race. Usually the members of the inferior race are described in negative stereotypes. Theses stereotypes are generalized as a standard image of that race and used as justification for supremacy of the other race. This 
type of apparent racism is called overt racism. It springs from an individual's hatred or dislike when an individual hates another one because of differences in race, color, culture, and ethnic background (Wilson xi). Gradually a group of people hates the existence of other group because of their racial traits and origin. Thus, one group evaluates another group's values, customs, and behavior as inferior.

Maya Angelou writes about stereotypes and culture of the African American people as it has being defined by white dominance society. In two different poems that follows each other in her collection entitled "The Thirteens (Black)" and "The Thirteens (White)". She shows the manner of different characters from both races blacks and whites:

\section{Your Momma took shouting, Your Poppa's gone to war, Your sister's in the street, Your brother in the bar, The thirteens. Right On. \\ Your cousin's taking smack Your uncle's in the joint, Your buddy's in the gutter, Shooting for his point, The thirteens. Right On. (11.1-10)}

The writer, in these two poems, uses the language of a street game called Dozens. The game includes insulting each other by saying rude words about each other but she uses thirteens (Hagen 47) instead of twelve to comment on the racial stereotype that has its root in the remote history of slavery, and discrimination. The characters are described as violent, rude, vulgar, immoral and corrupt. She writes these lines openly and plainly as Lyman B. Hagen states in "The Thirteens Black" she describes the life of black "in a manner that is a matter of fact and accepting"(47) as the poem ends with " I'd call you something dirty,/ but there just ain't nothing left,/ 'cept"(1l.13-15) . In "The Thirteens (White)" the writer shows equivalent character to that is shown in "The Thirteens (Black)":

Your Momma kissed the Chauffeur, Your Poppa balled the cook, Your sister did the dirty, In the middle of the book, The thirteens. Right On. (11.1-5)

By showing the similarity between the two races in their immoral behavior the writer wants to say that such a kind of stereotypes exist in both culture. Therefore, it should not be generalized. They are shown as having the equal trait but those immoral traits of white people are hidden, it is not open. The poet shows that white people are involved in dirty deeds. "Your brother jonesed your cousin/ in the back seat of the car."(11.8-9). In the culture of the white people, there are dishonorable activities and hypocrisy and desires for money and sex. She shows both races to be culturally equal, what is found in black race is also found in white race.

African Americans are described as not being civilized, as wild, as lazy, violent and rude. They are described as abusers and sensual that was the generally accepted description of black people by white people, therefore, white people prejudiced against them. They did not find them worthy of being their equal citizen. For white people freedom and civil right is culturally assumed but for the minorities it is the continuous struggle to survive discrimination and get civil rights.

In "My Guilt" she refers to over racism that is slavery of her ancestor. They were dehumanized and enslaved openly. She writes " My guilt is "slavery chains," too long/ the clang of iron falls down the years./ This brother's sold, this sister's gone"(1l.1-3) it shows that how they were and are victims of racism by referring to the heroes who fought for freedom throughout history.

In "The Calling of Names" Maya Angelou lists different names that throughout history they are called." He went to being called a colored man/ after answering to "hey, nigger"(11.1-2) it shows overt racism when African American people 
were assaulted by White people and called with offensive words. She mentions how they were called with racial pejorative "from colored man to Negro,/ with the $\mathrm{N}$ in caps."(11.6-7) and gradually these words changed "From Negro in caps/ to being a Jew." (1l.13-14) But still racism lingers even it is not overt.

Maya Angelou in her poems writes about another type of racism which is not discernible as overt racism. It is called institutional racism as it is defined by Stokely Carmichael and Charles V. Hamilton in Black Power: The Politics of Liberation in America as a kind of racism that " originates in the operation of established and respected forces in the society, and thus receives far less public condemnation than the first type"(4). Accordingly, racism from individual level moves to include a group or entire community hence it occupies every entity of the social life. The institutions inside the society are established and directed by individuals, who are members of the powerful group, and their policy. So the institutions will be at service of the more powerful group and support the prejudice of the powerful group.

For example in employment and workplaces, it is difficult for the minor race individuals to advance. They are regarded as not being able to advance, while members of the superior race who has the same quality even lesser ability they advance without difficulty. Here it is defined as institutional racism because it exists in the structure of different institutional entity (Wilson xii).

Similarly, Albert Memmi defines racism as a "structure" not merely a belief or a notion. For him racism means not only individual feeling but it is an established social structure and relationship in which the society is divided according to the existence of difference whether that it is cultural, religious, etc. Racism describes the nature of that difference in service of its own purpose. Those differences are degraded and devalued to justify the marginalization of the inferior group and the evaluation of the superior group. Accordingly, the differences are generalized to the whole group, as one race, and gradually it would be legitimate, (qtd in Appiah ix-x) and a racially segregated society is structured in which an environment imposed on minorities to live in a kind of life that is full of animosity and aggression.

In such a segregated society superior race enjoys their identity and all the facilities are available for them and they are socially privileged. They have chance to get or access the best works, services, positions inside society. Meanwhile, the other group suffers from lack of identity. They are prohibited to mix with the superior group. African Americans were likewise segregated from the privileged and more powerful group who were the white. Maya Angelou criticizes this type of institutional racism in her poems such as "Harlem Hopscotch" "Times-SquareShoeshine- Composition" " When I think about myself". She shows that the racial prejudice and institutional racism had made it difficult for African American to live a life like their counter part race, the white people who are living in the same country. They live in different economic and financial circumstances that make life easy for the white but difficult for the black because of their different races. In "Harlem Hopscotch" the writer shows the life of the black people who are living in the disadvantaged area of Harlem. She describes their life as a hopscotch game. In the first stanza the poet clarifies the rule of the game:

On foot down then hop!its hot

Good things for the one's that is got

Another jump, now to the left

Everyone for hisself.(1l.1-4)

The poet highlights discrimination against the black and affirms that "good things for the one's that is got" is available for those who are ruling authority who are rich and superior to the black who are living in the margin of society. Then the poet describes African Americans' life that is full of poverty. They need to survive poverty and 
racial segregation of their social system. As she writes in the second stanza:

In the air, now both feet down.

Since you black, don't stick around

Food is gone the rent is due

Curse and cry and then jump two.(11.5-8)

It shows that in the oppressed community of white supremacy the black people do not have the chance for economical development and it is difficult for them to be successful because of their race and racial segregation as she says " since you are black" you will not have the same chance of employment. She, further, refers to the discrimination in employment between black and white people, states " all the people out of work" Then the writer ends her poem with the racial prejudice against the black people as been described as loser in a white dominant society. She confidently says " they think I lost, I think I won"(1.14). The poet shows racism and its effect on the life of people and aims at brining about equality between both of them and improving the life of black race, as Carol E Neubauer states in her essay "Maya Angelou: Self and a Song of Freedom in the Southern Tradition," the poem shows "poet's own defense against incredible odd in the game of life"(134). It fights against supremacy and prejudice of the white people by being proud of her race.

In "Time Square shoeshine-composition" Maya Angelou refers to the life of African American in Northern by presenting the scene of life of the African American person in Northern America in Time Square. The speaker of the poem is working as a shoeshine. Through this character Maya Angelou refers to the state of African American people under a systematic racial oppression in which they do not have chance to show their ability and have better economical life, because of racial prejudice they are not accepted in a white dominant society as an equal citizen to the white people. Just they have the chance to be servants for the capitalist high class people who enjoy all the privileges of society.
They are not free economically and institutional racism stands as a barrier in front of their success. In the first stanza the speaker says:

I'm the best ever done it (pow pow)

That's my title and I won it

(pow pow)

I ain't lying. I am the best (Pow pow)

Come and put me to the test

(Pow pow) (11.1-4)

Despite of being a laboring class and performing their duty, the superior white class mistreats them as in this poem the man does not pay the required amount of money to the worker. At the end of the poem the speaker in a humorous tone criticizes the capitalist system and the oppressive life that is imposed on African American people by saying: " Say I am like a greedy bigot/ I am a capitalist, can you dig it"(1l.17-18) she satirizes the capitalist supremacy of white people that oppresses and enslaves black man in the society (Essick 42 ) as the speaker is not ready to accept the reduced amount of money and declaring that he is the supporter of capitalism.

In another poem entitled "When I think about myself" the writer gives an image of historical racial segregation that black people faces. The speaker of the poem is a black servant serving a white girl. When she thinks about her life, she tells about both overt and institutional racism. The speaker describes her life as "a dance that is walked/ a song that is spoke,"(11.4-5) it suggests the plight and persecution of their lives due to racial segregation and they did not live as they wanted. Then the speaker narrates the long history of persecution when she says:

Sixty years in this folk's world, The child I work for calls me a girl, I say yes ma'am for working sake.

Too proud to bend,

Too poor to break,

I laugh until my stomach ache, when I think about myself. (11.8-14) 
The speaker is not treated respectfully by her master. The master instead of appreciating her hard work insults and disrespects her, calls her a "girl" that suggests a belittling and humiliation. This shows the long history of overt racism that they faced. One can say that there is institutional racism since the poem does not specify the exact date and place means that still inside the society they are obliged to accept and live as underclass without having a chance to have better jobs. Then the writer criticizes the stereotypes that are attributed to her race. She refers to the fact that they justify their oppressive authority through showing stereotypes of black, are not more than lies " the tales they tell sound just like lying / they grow the fruit / but eat the rind"(11.17-19) she shows the economic oppression. She praises the greatness of their effort, for they have hand in the economic development of their own country but they do not have a share in it. The poet indirectly refers to slavery where African American faced overt racism as dehumanized as an object of earning more money for white people. The poem concludes with the idea of laughing and crying to show the confusion of their world and the misery that they face and to highlight their suffering and the brutal discrimination.

\section{Conclusions}

As it can be seen, throughout the study of Maya Angelou's poems, the poems capture different scenes of life of African American people among the white dominant society. She exposes their lives in contrast to the white people in her poems to denote the effect of racism and racial prejudice on black community. She shows them as a victim of a race that is not their fault but rather a condition imposed on them due to unfair assumption of racial attitude. Her poems simply screen those conditions by using literature as a medium to address the consciousness of their society, as well as to be consciousness-raising poems about the dark sides and harmfulness of racism. They address different types of racism, whether that racism is overt or more subtle with the aim of converting different types of discrimination to equality. The poems are embedded and set against the overt and institutional racial background of their society.

\section{References}

1. -Angelou, Maya. The Complete Collected Poems of Maya Angelou. New York: Raondom House, 1994.Print.

2. -Appiah, Kwame Anthony. Forward. Racism. By Albert Memmi. Minneapolis: Minneapolis University Press,2000. Print.

3. -Bloom, Harold, ed. Comprehensive Research Guide: Maya Angelou. New York: Chelsea House, 2001. Print.

4. -Bugeja, Michael J. Living Ethics: Developing Values in Mass Communication. Michigan: Allyn and Bacon,1996. Print.

5. -Carmichael, Stockely \& Charles V. Hamilton. Black Power: The Politics of Liberation in America. New York: Vintage Book, 1992. Print.

6. -Cox, Vicki . Maya Angelou: Poet. New York: Chelsea House, 2006. Print

7. -Essick, Kathy M. "On the Vernacular Language in the Poem" Comprehensive Research Guide: Maya Angelou. Ed. Harold Bloom. New York: Chelsea House, 2001.41-44. Print.

8. -Hagen, Lyman B. Heart of a Woman, Mind of a Writer and Soul of Poet: A Critical Analysis of the Writings of Maya Angelou. Lanham: University Press of America,1997. Print.

9. -Martinot, Steve. Introduction: the Double Consciousness. Racism. By Albert Memmi. Minneapolis: Minneapolis University Press,2000. Print.

10. -Massey,S. Douglas \&Nancy A. Denton. American Apartheid: Segregation and the Making of the Underclass. Massachusetts: Harvard University Press,1993.Print.

11. Neubauer, Carol E. " Maya Angelou: Self and a Song of Freedom in the Southern Tradition" Southern Women Writers: The New Generation.Ed. Tonette Bondinge. Tuscaloos: University of Alabama Press, 1990. 130-158. Print.

12. Wilson, Charles E. Race and Racism in Literature. London: Greenwood Press, 2005. Print. 